\title{
Muslimske brudegavers (mahr) rettslige status - noen refleksjoner ${ }^{1}$
}

Tone Linn Wærstad er førsteamanuensis ved Institutt for privatrett, UiO, der hun jobber med familierett, internasjonal privatrett og menneskerettigheter.

Epostadresse: t.l.warstad@jus.uio.no

Sammendrag:

Artikkelen undersøker den rettslige status til avtaler inngått i utlandet om muslimske brudegaver ( $m a h r$ ) når slike avtaler søkes oppfylt gjennom det norske rettssystemet. Artikkelen vektlegger spørsmål av internasjonal privatrettslig karakter som reiser seg der brudegaveavtalen kvalifiseres som en avtale om formuesordningen mellom ektefellene. Spørsmål om lovvalg og gyldighet drøftes i lys av den siste høyesterettsdommen som er avsagt om mahr i Norden, den svenske høyesterettsdommen fra 29. mars 2017, NJA 2017 s. 168. Artikkelen munner ut $\mathrm{i}$ en nærmere analyse av noen særskilte aspekter ved mahr-avtaler knyttet til grunnleggende regler om likestilling og rimelighet i kontraktsforhold, som domstolene bør være oppmerksomme på i saker om slike avtaler.

Nøkkelord:

Brudegave, mahr, muslimsk familierett, internasjonal privatrett, kvalifikasjon, lovvalg, avtalefrihet om lovvalg, domisil, vanlig bosted, ordre public.

\section{Innledning}

De senere årene har muslimske brudegaver (mahr) vært gjenstand for økt oppmerksomhet i de nordiske landene og nordisk rettslitteratur. Dette har sammenheng med demografiske endringer som følge av en $\emptyset \mathrm{kt}$ innvandring til Norden fra land der rettssystemet bygger på muslimsk rett, og der mange giftermål derfor inngås med innslag av muslimsk rett.

\footnotetext{
${ }^{1}$ Forfatteren $\emptyset$ nsker å takke den anonyme fagfellen for konstruktive kommentarer. Jeg ønsker også å takke Katrine Kjærheim Fredwall og Kirsti Strøm Bull for nyttige bidrag i arbeidet med artikkelen.
} 
Det at en $\varnothing$ kende del av befolkningen er muslimer og man kan anta at avtaler om mahr er utstrakt når disse inngår ekteskap, tilsier at det har aktualitet og betydning å fremstille reglene i norsk rett, drøfte enkelte typiske problemer og gi noen vurderinger av hvordan rettssystemet bør utvikles på dette området. ${ }^{2}$

Hovedtyngden av artikkelen vies problemstillinger som reiser seg om rettslig gjennomføring i Norge av en utenlandsk inngått avtale om mahr. De temaer som analyseres er følgende (punkt 4-7):

- Hvordan mahr-avtaler kan kvalifiseres når man skal finne frem til lovvalgsreglene i norsk rett, herunder særskilt om kvalifikasjon av mahr som en avtale om formuesordningen,

- Adgangen for ektefellene til å bestemme lovvalget (partsautonomi).

- Lovvalgsregelen der det ikke foreligger noen slik avtale.

- Vurderingen av avtalen etter at lovvalget er fastsatt i lys av tradisjonelle hensyn i internasjonal privatrett, og likestillingshensyn.

Som jeg vil redegjøre for nærmere nedenfor er avtaler om muslimske brudegaver et tema som det er forsket lite på i norsk rett og som det nærmest ikke finnes nasjonale rettskilder som belyser. Det er mange problemstillinger som potensielt vil reise seg i norsk rett knyttet til slike avtaler og jeg har valgt ut noen av disse. Siden den muslimske brudegaven er fremmed og ukjent i norsk rett, gir jeg ført en kort introduksjon til hva rettsinstituttet i korte trekk går ut på (punkt 2). Som et nyttig inntak til tematikken har jeg valgt å reflektere over to svenske høyesterettsdommer fra 2017 som vedrørte hvorvidt en avtale om mahr kunne gjennomføres som en gyldig avtale om formuesordningen etter svensk rett. ${ }^{3}$ Disse er de eneste sakene om gyldigheten av en mahr-avtale som har nådd den øverste domstolen i noen av de nordiske landene. Det vil spesielt legges vekt på den ene av disse dommene, NJA 2017 s. 168 ettersom den andre er et såkalt «notisfall» der det $\mathrm{i}$ den rettslige begrunnelsen bare henvises til begrunnelsen i NJA 2017 s. $168 .{ }^{4}$ De svenske dommene gis ikke noen selvstendig rettslig analyse, men brukes som en inngang til å se på dette

\footnotetext{
${ }^{2}$ Se Bredal og Wærstad 2014. Se Mehdi 2001 og Brattström og Sayed 2013 om dansk og svensk rett.

${ }^{3}$ NJA 2017 s. 168 (heretter omtalt også som den svenske dommen) og NJA 2017 N 6 (heretter også omtalt som notisfallet).

${ }^{4}$ De underliggende saksforholdene er likevel noe forskjellige og dette fører til at jeg også kommer til å knytte enkelte kommentarer til notisfallet underveis.
} 
problemfeltet i norsk rett som illustrasjon og argumentasjon. Jeg gir en kort presentasjon av dommene i punkt 3 .

\section{Introduksjon til hva avtaler om mahr er}

Mahr er en verdioverføring fra ektemannen til konen i forbindelse med inngåelsen av ekteskapet og avtales gjennom ekteskapskontrakten. Avtalen gjelder gjerne penger, men kan også bestå av for eksempel smykker og andre verdier. Ofte gis en del av den stipulerte verdien i forbindelse med ekteskapsinngåelsen og en annen del utsettes i tid. ${ }^{5}$ Kvinnen er eier av det hun mottar ved ekteskapsinngåelsen og ettersom muslimsk rett bygger på separat eiendom både under ekteskapet og etter samlivsbrudd mellom ektefellene, vil hun også få med seg midlene udelt etter ekteskapets avslutning. Dette vil også gjelde for den del av verdien som eventuelt er utsatt i tid og som hun vil ha krav på ved ekteskapsavslutningen. ${ }^{6}$

Mahr er en naturlig og integrert del av en muslimsk ekteskapskontrakt. Normalt innebærer dette at det er et nødvendig vilkår at mahr er avtalt for å kunne inngå et gyldig ekteskap innenfor muslimsk rett. ${ }^{7}$ Mahr har sin opprinnelse i koranen og har blitt utviklet gjennom de ulike islamske lovskolene og tatt inn i lovgivningen i forskjellige muslimske land. ${ }^{8}$ Dette at mahr kan ses som en religiøs plikt vanskeliggjør dens status i norsk rett ettersom det kan føre til forpliktelser når det gjelder beskyttelse av trosfriheten. Dessuten kan det vanskeliggjøre behandlingen av avtalen innenfor rammen av sivil rett. Til slutt reises det enkelte spørsmål knyttet til et kjønnsperspektiv i og med at brudegaveavtaler får forskjellige konsekvenser for kvinner og menn.

Et annet trekk som vanskeliggjør behandlingen av mahr-avtaler er at de varierer sterkt i karakter og konsekvenser. De kan gjelde alt fra kun symbolske verdier til å utgjøre store verdier; avtalen som den svenske dommen gjaldt, omhandlet for eksempel en verdi på ca. 1,5 millioner svenske kroner. Islamsk rett åpner for denne variasjonen. I enkelte tilfeller kan altså verdien utgjøre for eksempel et sølvsmykke og femti kroner, mens det i andre ekteskap kan være snakk om millioner av kroner, sågar midler som ektemannen ikke eier når avtalen inngås.

\footnotetext{
${ }^{5}$ Mehdi og Nielsen 2011, s. 13.

${ }^{6}$ Mehdi og Nielsen 2011, s. 13

${ }^{7}$ Hallaq, 2009 s. 277, Nasir, 2009 s. 87 flg., WLUML, 2006 s. 110.

${ }^{8}$ Mehdi og Nielsen 2011, s. 13.
} 
En vei inn i forståelsen av mahr som et rettslig institutt er å se nærmere på hvilke funksjoner og formål det har. ${ }^{9}$ En rekke studier i både i muslimske så vel som vestlige land av fenomenet viser at mahr kan oppsummeres med at ved siden av være en religiøs plikt og en integrert del av å inngå ekteskap, understreker betydningen og prestisjen av et ekteskap. ${ }^{10}$ I tillegg beskytter den kvinners $\emptyset$ konomiske stilling både under ekteskapet og etter et samlivsbrudd. Verdiene som avtales gjennom mahr-avtalen blir kvinnens eneeie og særeie. Det trenger dog ikke være slik at avtalen avhenger av kvinnens behov for forsørgelse. Islamsk rett har sitt eget underholdsinstitutt og mahr er klart avgrenset fra dette. ${ }^{11}$ Brudegaven understreker videre den sosiale statusen til ektefellene og deres familier og viser ektemannens seriøsitet ved å inngå ekteskap. ${ }^{12}$

Det er dessuten en viktig funksjon ved mahr at den bidrar til å opprettholde ekteskapet, ettersom den, gjennom regulering av muslimsk rett, gir begge ektefellene økonomiske incentiver til å ikke bryte ut av ekteskapet. ${ }^{13}$ For mannen sin del vil han normalt være forpliktet til å betale konen den del av brudegaven som ikke er betalt ved ekteskapet dersom han velger å avslutte samlivet. For kvinnens del virker det motsatt, hun vil normalt måtte betale tilbake det hun har mottatt i brudegave og ikke lenger ha rett til å motta den delen som ennå ikke er utbetalt, dersom det er hun som ønsker å skille seg. ${ }^{14}$

\section{Saker om mahr i svensk høyesterett; særlig om NJA 2017 s. 168}

De to svenske høyesterettsdommene, gjaldt gyldigheten av avtaler om mahr som var inngått mellom svensk-iranske ektepar. I forbindelse med ekteskapet inngikk partene avtaler om brudegave til konen som gikk ut på at mannen var forpliktet til å betale et visst antall gullmynter som ved rettssaken utgjorde ca. 1,5 millioner svenske kroner, når konen krevde dette. Begge avtalene ble krevet oppfylt i forbindelse med skilsmissen. I begge sakene var ektefellene iranske statsborgere, der én av partene var bosatt i Sverige og den andre var bosatt i Iran ved ekteskapets inngåelse. Spørsmålet som var oppe i begge sakene var for det første om lovvalgsregelen pekte ut iransk eller svensk rett, og deretter hvorvidt avtalen om mahr

\footnotetext{
${ }^{9}$ Se for eksempel fremstillingen til Nasir 2009, Fredriksen 2011, Løvdal 2008.

${ }^{10}$ Mehdi 2001, Bano 2011, Moors, 2011.

${ }^{11}$ Nasir 2009, s. 83-84, Fredriksen 2011, s. 150 flg., Løvdal 2008, s. 111.

${ }^{12}$ Fredriksen 2011 s. 151.

${ }^{13}$ Esposito 2001, s. 174, Roald 2001, s. 218 flg.

${ }^{14}$ Esposito 2001, s. 174, Roald 2001, s. 218 flg., Bano 2012a, s. 11, Bano 2012b, s. 261. Om rettsinsituttet mahr se nærmere for eksempel, Mehdi og Nielsen (red.) 2011, Løvdal 2008, Frantzen 2002 s. 340-344, Brattström \& Sayed 2013, Jänterä-Jareborg, 2018, Sayed 2008.
} 
kunne gjøres gjeldende. Høgsta domstolen kom i begge sakene til at svensk rett skulle benyttes for å bedømme tvistene og kom til at begge avtalene var ugyldige. I NJA 2017 s. 168 ble ekteskapet inngått i Iran i 1996. Konen (som til da hadde vært bosatt i Iran) flyttet til Sverige da hun fikk oppholdstillatelse ca. ett år etter vigselen og partene bodde sammen i Sverige i 16 år før skilsmissen. I saken anførte kvinnen at mahr-avtalen også var en avtale om iransk lovvalg. Hun fikk ikke medhold i dette. Høgsta domstolen kom frem til at avtalen måtte kvalifiseres som en avtale om formuesordningen mellom ektefellene og i mangel av en gyldig lovvalgsavtale mellom ektefellene, at regler om partenes bosted(«hemvist») ville bestemme lovvalget. Partene ble ansett for å ha «hemvist» i Sverige ved ekteskapsinngåelsen og etter en nærmere bedømmelse av mulige særskilte unntak for mahr-avtalen, kom Høgsta domstolen til at avtalens gyldighet skulle prøves fullt ut etter svensk rett. Konsekvensen ble at avtalen ble ansett å være ugyldig.

Det som er poenget med dommen i denne sammenheng er å bruke den som et utgangspunkt for å reflektere rundt brudegaveavtaler mer generelt i norsk rett. En slik sak vil kunne være aktuell også i Norge og dommen reiser mange interessante problemstillinger som det vil være nyttig å være oppmerksomme på. Det er spesielt tre temaer som peker seg ut. Det første er hvordan den aktuelle lovvalgsregelen i norsk rett, regelen om at partenes første felles domisilland blir retten som skal benyttes, ville vurderes i en tilsvarende norsk sak. Det andre er hvorvidt vi kunne få en rimelighetsvurdering av avtalen som et ledd i lovvalgsvurderingen (spørsmålet om partenes domisil), eller om dette i norsk rett (dersom utenlandsk rett ville være aktuelt for å bedømme saken), ville måtte skytes ut i en senere vurdering av ordre public (hvorvidt resultatet i saken ville stride mot grunnleggende prinsipper i norsk rett). Til slutt er det verdt å se nærmere på enkelte spesielle hensyn som reiser seg i saker om den muslimske brudegaven, knyttet til likestilling, og rettslig systematikk og utvikling. Disse tre elementene som er spesielt interessante ved dommen, vil jeg redegjøre for i sammenheng med fremstillingen av norsk rett nedenfor.

\section{Nærmere om lovvalg for avtaler om mahr med tilknytning til utenlandsk rett}

\section{Kvalifikasjon av mahr-avtaler}

En problemstilling som stadig tas opp både i domstolene og i litteraturen er kvalifiseringen av mahr når det gjelder lovvalgsreglene, altså hvordan man skal klassifisere mahr, når man skal bestemme hvilket lands rett som skal benyttes i saken, der saken har tilknytning til flere rettssystemer. Domstolen må først avgjøre hvilket rettsområde avtalen skal sorteres under. 
Dette omtales i internasjonal privatrett som kvalifikasjon. ${ }^{15}$ Dersom mahr kvalifiseres som en alminnelig kontrakt vil andre lovvalgsregler gjelde enn om den plasseres som en avtale om formuesordningen mellom ektefeller.

Spørsmålet har skapt hodebry for både domstoler og rettsforskere i de skandinaviske land. ${ }^{16}$ Grunnen er at en mahr-avtale er helt fremmed for de skandinaviske rettssystemer og kan, som vi har sett, variere sterkt i formål og karakter. I norsk rett er det liten eller ingen rettspraksis som omhandler mahr direkte og det har så vidt meg bekjent aldri vært reist et krav om utbetaling av mahr i norsk rett. ${ }^{17}$ I Sverige der imot har spørsmål om avtaler om mahr vært behandlet i flere underrettsdommer gjennom de siste årene, men rettspraksis har vært sprikende og dommene viser med tydelighet at det er kompliserte og vanskelige spørsmål som reiser seg om lovvalget. ${ }^{18}$ Det var mot denne bakgrunnen at den svenske Høgsta domstolen tok inn de to nevnte sakene for behandling. I den svenske høyesterettsdommen (NJA $2017 \mathrm{~s}$. 168) kommer Høgsta domstolen frem til at hver avtale må vurderes for seg nettopp fordi mahr-avtaler kan variere slik i art og formål. Dette er også stor enighet om i rettslitteraturen. ${ }^{19}$ Mot denne bakgrunn skal jeg nå redegjøre for noen måter mahr kan kvalifiseres under i norsk rett når lovvalget skal avgjøres.

Det vil som nevnt, kunne være mulig å kvalifisere en avtale om mahr som alminnelig kontraktsrett, dette vil typisk være dersom den anses som en gave fra ektemannen til konen. Dersom mahr-avtalen kvalifiseres som gave er avtalen i norsk rett ansett å følge alminnelige kontraktsrettslige lovvalgsregler. Mahr kan ved første øyekast virke som å passe godt under kategorien «gave». Normalt vil jo mahr nettopp være en gave fra ektemannen til konen som gis i forbindelse med ekteskapsinngåelsen. I norsk rett, slik den har vokst frem i rettspraksis, er det to vilkår som må være oppfylt for at en gave skal foreligge: gavehensikt og formuesforskyvning. ${ }^{20}$ Mahr passer ikke med gavebegrepet i norsk rett der det forutsettes at

\footnotetext{
${ }^{15}$ Cordes, Stenseng, Lenda 2010, s. 83 flg., Frantzen 2002, s. 141.

${ }^{16}$ Se Løvdal 2008, Mehdi og Jørgensen 2011, Frantzen 2002 s. 340-344. Lovgiverne i de nordiske landene har i liten grad vært oppmerksomme på tematikken.

${ }^{17}$ Se Løvdal 2008 for omtale og analyse av to eldre underettssaker fra 1983 og 1986, der det kommer frem at det forelå en avtale om brudegave i ekteskapskontraktene mellom partene, den ene (1983 dommen) var et spørsmål om underhold og den andre (fra 1986) var et spørsmål om ekteskapets gyldighet.

18 Jänterä-Jareborg 2018, s.

19 Løvdal 2008, Løvdal 2011, Fredriksen 2011, Wærstad 2017.

${ }^{20}$ Se Rt. 2014 s. 1248 og Rt. 2017 s. 707. Se Bull 1993a s. 128-156 for en gjennomgang av gavebegrepet slik det har vokst frem i norsk rett
} 
gaven gis frivillig, ettersom mahr er et nødvendig vilkår for å inngå et ekteskap etter muslimsk rett mange steder. Dette passer ikke med vilkåret om gavehensikt. Dessuten vil en avtale med utsatt brudegave kunne passe dårlig med vilkåret om formuesforskyvning. ${ }^{21}$

Dersom mahr kvalifiseres som gave, er det det landet som avtalen har sin sterkeste tilknytning til som skal legges til grunn. Dette er i juridisk teori utledet av Rt. 1923 II s. 58 (Irma Mignon) som omhandlet kollisjon mellom to norske skip i engelsk farvann. Saken ble bedømt etter norsk rett ettersom den ble ansett å ha sterkest tilknytning til Norge. Senere har regelen gjerne blitt omtalt som «den individualiserende metode» eller rett og slett som «Irma Mignonformelen».

Der familierettslige lovvalg er aktuelle, vil et første skille i norsk rett være mellom $\emptyset$ konomiske og personlige rettsvirkninger av ekteskap. Dersom mahr klassifiseres som en personlig virkning av ekteskapet, vil lovvalget peke ut partenes hjemlands rett. ${ }^{22}$ Dette vil typisk gjelde der man kvalifiserer mahr som en avtale om underhold. For at en virkning skal anses som personlig vil den fastlegge ektefellenes rettigheter og plikter i personlige og praktiske forhold. ${ }^{23}$ Grunnen til at underhold regnes som en personlig virkning kommer nok av at den er knyttet til ektefellens behov for underhold. Ettersom sakene om mahr mest sannsynlig vil komme opp i forbindelse med skilsmisse, vil det være snakk om underholdsbidrag etter skilsmisse. I islamsk rett fremstår riktignok aktualiteten for å klassifisere mahr som underhold, som liten. Islamsk rett har sitt eget underholdsinstitutt og mahr er klart avgrenset fra dette. ${ }^{24}$ Forpliktelsen om å betale brudegaven er ikke avhengig av konens behov for underhold. Det har derfor formodningen mot seg å anse mahr som en form for underholdsbidrag, selv om det underliggende formålet til mahr-avtalen også er at kvinnen skal beskyttes $\emptyset$ konomisk ved et brudd mellom partene.

Dersom mahr derimot klassifiseres som en økonomisk effekt av ekteskapet, og da typisk som en del av formuesordningen, vil saken avgjøres etter partenes første felles domisilland. Lovvalgsreglene er basert på sedvanerett og er stadfestet i høyesterettspraksis. ${ }^{25}$ Mahrs funksjon som kvinnens eneeie, som hun udelt tar med seg ved ekteskapsoppløsning (riktignok normalt under forutsetning at det er mannen som tar ut skilsmisse), er et klart argument for at

\footnotetext{
${ }^{21}$ Se nærmer om dette i Wærstad 2017, kapittel 11.

22 Thue 2002, s. 384, Bull 1993b, s. 528, Holmøy, Lødrup og Asland 2013, s. 202.

23 Thue 2002, s. 382.

${ }^{24}$ Nasir 2009, s. 83-84, Fredriksen 2011, s. 150 flg., Løvdal 2008, s. 111.

${ }^{25}$ Rt. 1995 s. 1415 (Joint accounts). Se nærmere om dette nedenfor.
} 
det er formuesordningen som er rettsområdet som skal bestemme lovvalget og dette har også blitt resultatet i en rekke dommer i ulike europeiske land. Dette alternativet tas derfor ut til nærmere vurdering i denne artikkelen.

De norske lovvalgsreglene om rettsvirkninger av ekteskap er i stor grad ulovfestede og baserer seg til dels på eldre og usikre rettskilder. Rettskildebildet kompliserer derfor prosessen med å finne frem til lovvalget. ${ }^{26}$ Dette kan føre til at krav om oppfyllelse av mahr-avtaler i norsk rett vil være vanskelige å avgjøre.

For å oppsummere vil rettstilstanden om avtaler om mahr i norsk rett vanskeliggjøres av at mahr-instituttet er fremmed i norsk rett og kan variere sterkt i både funksjon og karakter, og at den norske rettskildesituasjonen i internasjonal privatrett på familierettsområdet er uklar og utdatert på ulike måter.

\section{Mahr kvalifisert som en avtale om formuesordningen}

\section{Innledning}

Som allerede nevnt vil mahr typisk ses som en avtale om formuesordningen. Dette er blitt gjort $\mathrm{i}$ en rekke saker i ulike europeiske rettssystemer, herunder i de skandinaviske landene. ${ }^{27}$ Mahrs funksjon som kvinnens eneeie, som hun udelt tar med seg ved ekteskapsoppløsning er et klart argument for at det er formuesordningen som er rettsområdet som skal bestemme lovvalget. Verdiene som avtales gjennom mahr-avtalen blir altså ansett å være kvinnens eneeie og særeie. ${ }^{28} \mathrm{Jeg}$ analyserer i det videre ut i fra at mahr-avtalen skal kvalifiseres som en del av formuesordningen mellom ektefellene.

I tvister vedrørende formuesordningen mellom ektefeller er det først naturlig å avklare om ektefellene har laget en avtale om selve lovvalget. Som vi skal se nedenfor er det usikkert i hvilken grad ektefellene gyldig kan inngå en avtale om lovvalg i disse tilfellene. Jeg ser på dette først for så å vurdere lovvalget der det ikke er inngått en slik avtale. ${ }^{29}$ Som regel vil det

\footnotetext{
${ }^{26}$ Se nærmere om dette i Frantzen 2002, s. 71-88, Thue 2002, s. 508 og Nesvik 2014 s. 9.

${ }^{27}$ Se Løvdal 2008 for analyse av dommer i skandinavisk, britisk og fransk rett. Se også flere bidrag i Mehdi og Nielsen (red.) 2011.

${ }^{28}$ Mehdi og Nielsen 2011, s. 13

${ }^{29}$ Frantzen 2002, s. 274 (med videre henvisninger).
} 
ikke foreligge noen slik avtale og det som blir praktisk viktig er derfor hvilket lands rett lovvalgsreglene peker ut.

\section{Adgangen til å avtale lovvalg om formuesordningen}

Det er uklart i norsk rett hvorvidt en avtale om lovvalg om avtaler om formuesordningen i internasjonale ekteskap, vil være gyldig. Dette er i motsetning til svensk rett, der avtaleadgangen er regulert gjennom lov i lagen (1990:272) om internationella frågor rörande makars och sambos förmögenhetsförhållanden (LIMF) § 3 .

Den nærmere adgangen i norsk rett til å avtale lovvalg for formuesordningen mellom ektefeller i internasjonale ekteskap er berørt i to saker fra Høyesterett. I Rt. 1995 s. 1415 (Joint Accounts) uttales det at det er usikkert om det er adgang til lovvalgsavtaler i norsk rett, men at det uansett må kreves en klar avtale om lovvalget før dette spørsmålet kommer på spissen. Partene hadde inngått avtalen som utgjorde grunnlaget for tvisten, etter et utenlandsk rettssystem. Avtalen ble ikke av Høyesterett ansett for også å innebære en avtale om lovvalget. ${ }^{30}$ Det er i lys av dommen naturlig å anse at heller ikke en avtale om mahr, uten noen nærmere omtale av lovvalgsspørsmålet, vil anses som en avtale mellom ektefellene om at lovvalget skal være det landets rett som mahr-avtalen eventuelt er laget under. ${ }^{31}$

Om adgangen til å inngå en slik særskilt avtale om lovvalget, har Høyesteretts kjæremålsutvalg uttalt i HR-2007-194-U at det vil være adgang for å avtale lovvalg om formuesordningen også der det endrer et allerede etablert lovvalg. Kjennelsen må riktignpk leses ut i fra sakens omstendigheter, der lovvalget som var foretatt fremsto som uproblematisk og dessuten at det var valgt norsk rett, som domstolen nok vil være mer villig til å godkjenne enn der utenlandsk rett er valgt. Det gis ikke noen anvising på den nærmere avgrensning av avtalefriheten i kjennelsen, men det var snakk om parter med sterk tilknytning til Norge og et lovvalg som i det store og det hele ikke ville reise prinsipielle spørsmål eller problemer for partene i saken. Det anføres ingen rettslige argumenter til støtte for at det generelt skal foreligge en vid adgang til avtalefrihet om lovvalget i avtaler om formuesordningen og dette tilsier også at kjennelsen i liten grad kan sies å gi argumenter for avtalefrihet om lovvalg

\footnotetext{
${ }^{30}$ Rt. 1995 s. 1415 , på s. 1420.

${ }^{31}$ Se også RG 1983 s. 1021 for et annet eksempel der en ekteskapsavtale inngått etter utenlandsk rett ikke ble ansett for å innebære et avtalt lovvalg mellom ektefellene. Den svenske Høgsta domstolen kom for $\emptyset$ vrig til samme resultat i den svenske dommen, som vil bli nærmere omtalt under.
} 
utenfor situasjoner der partene og saken har en sterk tilknytning til det landets rett som er valgt. ${ }^{32}$ Når det gjelder avtaleadgang mellom ektefeller til å bestemme lovvalget for formuesordningen, foreligger det etter min mening, en begrenset adgang etter norsk rett, der den nærmere grensen er uklar, men bør bestemmes av hvor nær tilknytning partene og forholdene som det tvistes om, har til det landets rett som er valgt. Frantzen argumenterer for at ektefellene må kunne velge et land der en av dem er statsborger eller har domisil, samt første felles domisilland, ettersom dette utgjør de sentrale tilknytningsfaktorene i familieformueretten og sikrer hensyn til forutsigbarhet og klarhet. ${ }^{33}$

\section{Det foreligger ikke avtale om lovvalget mellom ektefellene}

Dersom det ikke foreligger noen avtale om lovvalget mellom ektefellene, må man falle tilbake på de alminnelige lovvalgsreglene. Lovvalgsreglene om formuesordningen i norsk rett er, som nevnt, ulovfestede og har vokst frem gjennom rettspraksis. I Rt. 1995 s. 1415 (Joint Accounts) stadfestes det at ektefellenes første felles domisilland vil gjelde for formuesordningen. ${ }^{34}$ Det betyr at det første landet som ektefellene får felles domisil i, vil være det landet hvis rett formuesordningen reguleres under. Et første felles domisilland vil normalt være etablert når ektefellene har vært bosatt i det aktuelle landet $\mathrm{i}$ en viss tid og i tillegg har planer om å fortsette å bo der. ${ }^{35}$ Det gjelder videre et prinsipp om formuens uforanderlighet som har vokst frem i rettspraksis, som betyr at når lovvalget først er etablert kan det ikke forandres for eksempel ved at partene flytter og etablerer et nytt felles domisil. Det vil riktignok være mulige unntak til dette prinsippet. ${ }^{36}$

\section{Nærmere om domisilprinsippet som avgjørende for lovvalget}

Hovedregelen er dermed at partenes første felles domisilland blir det landets rett som saken skal prøves under. Dette er også i hovedsak situasjonen i svensk rett, der vurderingen knyttes til begrepet «hemvist», som har likheter, men som ikke er sammenfallende med det norske domisilbegrepet. Spørsmålet om partenes «hemvist» fikk stor betydning i den svenske dommen og jeg skal se nærmere på Høgsta domstolens vurdering og så sammenligne med norsk rett.

\footnotetext{
${ }^{32}$ Se nærmere om kjennelsen i Wærstad 2017, s. 285-287 og Nesvik 2014, s. 38-39.

33 Frantzen 2002, s. 288 flg. Holmøy, Lødrup, Asland 2013 slutter seg til denne vurderingen (s. 204-205).

${ }^{34}$ Doktrinen ble først virkelig etablert i Rt. 1942 s. 214 (Boman Hansen-dommen).

${ }^{35}$ Se nærmere om domisilprinsippet i f.eks. Thue 2002 kapittel 4.

${ }^{36}$ Se nærmere om dette i Frantzen s. 221 flg., Bull 1993b, s. 533.
} 
Den aktuelle bestemmelsen som ble vurdert i den svenske dommen var «lagen (1990:272) om internationella frågor rörande makars och sambos förmögenhetsförhållanden (LIMF)» § 4 første ledd, som stadfester at der partene ikke har bestemt lovvalget gjennom avtale, gjelder loven i det landet der de tok bosted da de giftet seg. ${ }^{37}$ I loven er hemvist definert i § 19 som: «Vid tillämpningen av denna lag skall den som är bosatt i en viss stat anses ha hemvist där, om bosättningen med hänsyn till vistelsens varaktighet och omständigheterna i övrigt får anses stadigvarande.» To vilkår må være oppfylt for at en person skal bli ansett for å ha endret sin «hemvist»: For det første må personen ha flyttet til det nye landet. Dette er et objektivt vilkår. For det andre må personen ha til hensikt å bli boende i det nye landet i en betydelig tid fremover. Dette er et subjektivt vilkår, men med et betydelig objektivisert innhold i og med at bedømmelsen vil ta utgangspunkt i et «gjennomsnittsmenneskes» hensikter i en tilsvarende situasjon. ${ }^{38}$ Den nærmere bedømmelsen må gjøres ut i fra omstendighetene i saken og begrepet er ansett for å være fleksibelt i så måte. ${ }^{39}$ I norsk rett samsvarer hemvist-begrepet med det norske domisil-begrepet der det subjektive elementet om vilje til varig opphold også er underlagt en objektivisert målestokk om hva som «gjennomsnittelig må forventes å være hensikten hos personer som befinner seg i en lignende situasjon». ${ }^{40}$ Men både det svenske hemvist-begrepet og det norske domisil-begrepet er ansett for å være fleksibelt når en for kategorisk anvendelse av vilkårene vil føre til urimelige resultater. ${ }^{41}$

I svensk rett er det slik at dersom partene etter å ha etablert et første felles domisil siden flytter til et nytt land og tar bosted der, skifter lovvalget til dette landet fra tiden etter at partene har bodd i landet $\mathrm{i}$ to år. I den svenske saken hadde partene bodd mange år i Sverige og det var derfor ikke tvil om at lovvalget var endret til svensk rett. LIMF $§ 5$ første ledd bestemmer at selv om partene skal ha skiftet bostedsland underveis, så vil en avtale være gyldig om den stemmer overens med den loven som skulle benyttes da ekteskapet ble inngått (avsnitt 27 i dommen). Dette gjelder både formell og materiell gyldighet. ${ }^{42}$ Det sentrale spørsmålet i bedømmelsen av partenes hemvist blir ifølge dommen, hvorvidt en av ektefellene hadde bosted i Sverige og hensikten til ektefellene var å bosette seg i Sverige etter

\footnotetext{
${ }^{37}$ Hvorvidt en avtale om mahr vil kunne sies å være en avtale om lovvalget ble behandlet i dommen og er også et aktuelt spørsmål i norsk rett, som jeg vil behandle under.

${ }^{38}$ Bogdan 2014, s. 134-135, med videre henvisninger til svenske forarbeider, rettspraksis og litteratur.

39 Pålsson 2006, s. 26, Bogdan 2014 s. 135-138.

${ }^{40}$ Cordes, Stenseng, Lenda 2010 s. 129-130.

${ }^{41}$ Cordes, Stenseng, Lenda 2010 s. 130.

42 Bogdan 2014, s. 186.
} 
ekteskapsinngåelsen og også gjorde det. Dersom svensk rett pekes ut, skal avtalen være gyldig om den er i tråd med svensk rett. Dersom det er iransk rett som pekes ut, skal avtalen anses gyldig dersom den er forenlig med iransk rett.

Det stadfestes at det fremgår av utredningen til saken at partene hadde til hensikt å bosette seg i Sverige etter ekteskapets inngåelse og det var det kvinnen også gjorde da hun omtrent ett år etter, fikk oppholdstillatelse. Det slås fast at det var klart at Sverige ble første felles bostedsland og at svensk rett derfor skulle gjelde i saken. Dommen har blitt ansett for (og kritisert for) å legge stor vekt på den subjektive siden ved hemvist-begrepet og parets intensjon om at de begge skulle være bosatt i Sverige etter vigselen. ${ }^{43}$ Som jeg skal redegjøre for nedenfor, går tendensen i norsk rett i motsatt retning mot å legge mindre vekt på intensjon om varig opphold og mer på hvor personen faktisk bor. ${ }^{44}$ I dette lyset fremstår argumentasjonen til Høgsta domstolen på dette punktet, som overraskende.

\section{Nærmere om lovvalgsvurderingen etter norsk rett}

Et spørsmål som peker seg ut, og som har interesse i norsk rett, er altså hvorvidt partene i en sak som den svenske har etablert et første felles domisil allerede ved vigselen, og, om man kommer frem til at de den første tiden etter vigselen hadde hvert sitt domisil, hvorvidt dette vil ha noe å si for vurderingen av lovvalget når avtalens gyldighet skulle bedømmes. Dette skal jeg se nærmere på i det følgende.

Som redegjort for over, er det til dels sammenfall mellom det svenske hemvist-begrepet og det norske domisil-begrepet. Tvil om innholdet i domisilbegrepet kommer som oftest opp der omstendighetene tilsier at ett bestemt land bør utvelges, selv om gjerne ett av de to vilkårene om faktisk bosted og intensjon om å bli boende, ikke foreligger. ${ }^{45}$ Det synes å være enighet $\mathrm{i}$ norsk rettslitteratur om at et mer fleksibelt domisilbegrep, der alle relevante omstendigheter

\footnotetext{
43 Jänterä-Jareborg 2018, Brattström og Sayed 2019, s. 51-54.

${ }^{44}$ Se punkt 6 under.

${ }^{45}$ Cordes, Stenseng, Lenda 2010 s. 130-131 med videre henvisninger, Bogdan 2014 s. 138 med videre henvisninger.
} 
tas i betraktning, kan anlegges for å unngå urimelige og uhensiktsmessige resultater i den enkelte sak. ${ }^{46}$

Videre kan man spørre om ikke senere års lovgivning på familierettsområdet i Norge som i stor grad benytter begrepet «vanlig bosted» i regelverk som gjelder internasjonal privatrett, også kan ha betydning for innholdet i domisilbegrepet. ${ }^{47}$ «Vanlig bosted»-begrepet tilsvarer i stor grad begrepet «habitual residence» som benyttes som et internasjonalt begrep blant annet i flere av Haag-konvensjonene og i relevant EU-rett. ${ }^{48}$ Begrepet har et objektivt innhold om faktisk bosted, og det stilles ikke like strengt krav til intensjon om varig opphold som der domisilbegrepet anvendes. ${ }^{49}$ I følge forarbeidene til disse lovene, der spesielt ny lov om arv og dødsboskifte er sentral (ettersom den inneholder en særskilt lovvalgsbestemmelse, der vanlig bosted er tilknytningskriterium), vil en persons vanlige bosted, måtte vurderes konkret etter en samlet vurdering av en rekke faktorer, med utgangspunkt $i$ der en person bor og har sentrum for sine livsinteresser. ${ }^{50}$ Å nedjustere kravet til intensjon om varig opphold begrunnes i praktiske hensyn som at det kan være vanskelig å bevise og at økt mobilitet gjør det er mindre treffende å kreve intensjon om varig opphold for å stadfeste personalstatuttet. ${ }^{51}$ Det stadfestes likevel at begrepet ikke kan knyttes til noen klar definisjon, det er fleksibelt og vil utvikles over tid. ${ }^{52}$

For å oppsummere er det altså innbygget en stor fleksibilitet i å bestemme domisil og vanlig bosted i norsk internasjonal privatrett på familierettsområdet. Med en jevn utvikling vekk fra subjektive krav i norsk familie- og arverett de siste årene mot et mer rendyrket vanlig bostedbegrep, kan det nok argumenteres for at også hjemlandsrettsvurdering som bygger på

\footnotetext{
${ }^{46}$ Cordes, Stenseng, Lenda 2010, s. 131 med videre henvisninger, Holmøy, Lødrup, Asland 2013 s. 57-58, Thue 2002 s. 81-82, Giertsen 1995, s. 275.

${ }^{47}$ Dette gjelder lov 12. mai 2015 nr. 27 om forsvunne personar $\S 2$ (jf. Prop.18 L (2014-2015) side 26-27), lov 4. september 2015 om gjennomføring av konvensjon 19. oktober 1996 om jurisdiksjon, lovvalg, anerkjennelse, fullbyrdelse og samarbeid vedrørende foreldremyndighet og tiltak for beskyttelse av barn $\S 8$, lov 8 . april 1981 nr. 7 om barn og foreldre § 81, § 81 a, § 82, § 83 og $\S 84$ a, lov 17. juli $1992 \mathrm{nr} .100$ om barneverntjenester $\S 1-$ 2, lov 4. juli 1991 nr. 47 om ekteskap § 30 d og lov 16. juni 2017 nr. 48 om adopsjon $\S \S 18$ til 22 og $\S 43, \S 44, \S$ 46 og $§ 48$.

48 Prop.107 L (2017-2018) Lov om arv og dødsboskifte (arveloven), s. 265. Kvisberg 2012, kapittel 4.3, Thue 2002 s. 93-105.

${ }^{49}$ Kvisberg 2012, s. 160-164, Thue 2002, s. 93-105.

50 Prop.107 L (2017-2018) Lov om arv og dødsboskifte (arveloven), s. 265.

${ }^{51}$ Personalstatuttet er det landets rett der

52 Prop.107 L (2017-2018) Lov om arv og dødsboskifte (arveloven), s. 265.
} 
domisilbegrepet i den ulovfestede lovvalgsregelen for formuesordningen t kan sies å bevege seg i denne retningen mer generelt. ${ }^{53}$

Thue omtaler nettopp et slikt tilfelle som har sin parallell i den svenske dommen, nemlig der en mann bosatt i Norge inngår ekteskap med en kvinne bosatt utenfor EØS-området i hennes hjemland. ${ }^{54}$ Han mener at det er utenkelig at kvinnen kunne få norsk domisil ved vigselen og at det ville være i tråd med domisilprinsippet at hun først skiftet domisil når hun fikk bosettingstillatelse, som i norsk rett var satt til tre år etter ekteskapets inngåelse. Frantzen mener at Thue anlegger en for streng norm og at et domisilskifte ville skje tidligere, men mener likevel at ektefellene ville være uten felles domisilland i den første tiden etter vielsen. En samstemt norsk teori anlegger som et absolutt minstevilkår at personen fysisk har flyttet til Norge for at domisilskifte kan skje. ${ }^{55}$ Det har altså formodningen mot seg at ektefellene ville anses å ha etablert Norge som felles domisilland allerede ved vigselen i en tilsvarende sak som i den svenske dommen. Som redegjort for over, er det en generell tendens i norsk familierett at det legges mindre vekt på subjektiv intensjon om varig opphold når lovvalget skal bestemmes. Dette trekker også i retning av at kvinnen ikke ville anses å ha gjort noe domisilskifte ved vigselen. Jeg synes at tilfellet i den svenske dommen er nettopp et eksempel der det å anlegge norsk rett som hjemlands rett vil være kategorisk og urimelig sett i lys av den sterke tilknytningen kvinnen hadde til iransk rett da avtalen ble inngått og den tilsvarende svake tilknytningen hun hadde til ektemannens hjemlands rett. Det er gode argumenter for å anse Iran som kvinnes domisil da mahr-avtalen ble inngått, selv om det kommer klart frem i dommen at hun hadde intensjon å bosette seg i Sverige og at det subjektive vilkåret om intensjon om varig opphold i Iran således ikke var oppfylt. Hun hadde aldri bodd noe annet sted enn i Iran og en plan om å flytte til Sverige var over ett år frem i tid ved vigselen.

Dersom vi i det følgende forutsetter at ektefellene ikke ville ha etablert et felles domisil i den første tiden etter ekteskapsinngåelsen, blir det neste spørsmålet i så fall hvilket lands rett som gjelder for avtaler inngått om formuesordningen dem imellom i denne perioden. Dette er usikkert i norsk rett. En mulig løsning vil være å anse at når ektefellene først etablerer et felles domisilland, vil dette være avgjørende også for avtaler om formuesordningen som er foretatt i

\footnotetext{
${ }^{53}$ Se lignende argumenter på barneloven og barnevernlovens område i Kvisberg 2012, s. 160-164.

54 Thue 1997.

${ }^{55}$ Se blant annet Gaarder/Lundgaard 2000 s. 141, Thue 2002 s. 79.
} 
forkant av dette, men det er ingen autoritative rettskilder som tilsier en slik løsning. Thue beskriver denne perioden som uavklart med hensyn til hvilke lovvalgsregler som gjelder etter norsk rett, men tar ikke opp direkte spørsmålet om regelen om første felles domisil etter at dette er etablert, slår gjennom for avtaler inngått i tiden før, dvs. før første felles domisil er etablert. ${ }^{56}$ Spørsmålet er meg bekjent ikke inngående redegjort for i rettskilder (herunder rettslitteraturen). Frantzen synes å forutsette at et senere etablert lovvalg gjennom et felles domisil vil bestemme lovvalget også for avtaler inngått før felles domisil etableres, men drøfter ikke spørsmålet direkte. ${ }^{57}$ Utgangspunktet er nok at første felles domisilland-regelen vil få tilbakevirkende betydning for avtaler inngått også før felles domisil ble etablert der dette vil føre til gode og rimelige løsninger. ${ }^{58}$ Men den svenske saken ville nok bli ansett som et tilfelle der reelle hensyn ville tale for at man ikke lot første felles domisil-regelen slå igjennom for avtaler dannet før partene hadde etablert et første felles domisilland. Etter min mening bør en ta hensyn til partenes og avtalens sterke tilknytning til iransk rett. Et alternativ ville være å unders $\varnothing$ ke felles statsborgerskap som en tilknytningsfaktor så vel som nærmeste tilknytning i søken etter en rimelig løsning.

Dette må i neste omgang vurderes opp mot eventuelle preseptoriske regler i det norske rettssystemet og eventuelle skranker gjennom regelen om unntak der resultatet av å anlegge det andre landets rett strider mot ordre public. ${ }^{59}$ Hensynet til selve avtalens tilknytning til iransk rett er spesielt fremtredende i saken og dette bringer meg over til neste spørsmål: Hvordan får rimelighetsvurderinger av selve avtalen og dens virkninger betydning for lovvalgsvurderingen? I den svenske dommen ble rimelighetsvurderinger trukket inn i selve lovvalgsvurderingen, altså vurderes ikke avtalen etter iransk rett og så gjøres en vurdering av om dette kan opprettholdes i svensk rett, men heller i en vurdering av om det er svensk eller iransk rett som skal gjelde for spørsmålet om avtalens gyldighet. Dette er en interessant løsning som kan være verdt å studere nærmere også i norsk rett. Så vidt meg bekjent, har vi ikke noen rettskilder som gir noen direkte anvisning på en slik løsning i norsk rett. Jeg ser først nærmere på den argumentasjonen i den svenske dommen her, og vurderer så dette nærmere i norsk rett nedenfor under punkt 7.

\footnotetext{
56 Thue, 2002 s. 400.

${ }^{57}$ Frantzen 2002, s. 187-188.

${ }^{58}$ Både Frantzen 2002, s. 187-188 og Holmøy, Lødrup, Asland 2013, s. 201-202 synes å forutsette et slikt utgangspunkt.

${ }^{59}$ Se nærmere om internasjonalt preseptoriske regler og ordre public reservasjonen i familierettslige fremstillinger i for eksempel Frantzen 2002, kapittel 7, Holmøy, Lødrup, Asland 2013, s. 201-202
} 
Det slås i den svenske dommen fast at LIMF § 5 ikke skal tolkes motsetningsvis (avsnitt 33). Det betyr at i et tilfelle der svensk rett er utpekt, og partene ikke har inngått en gyldig avtale etter svensk rett, slik domstolen kommer til (avsnitt 41) betyr ikke det nødvendigvis at avtalen blir ugyldig. Med henvisning til forarbeidene til äktenskapsbalken (SFS 1987:230), kommer domstolen til at dette ville gå for langt. I de nevnte forarbeidene står det at man skal være forsiktig med å underkjenne rettshandlinger som partene har gått ut i fra at skal gjelde, selv om handlingen ikke stemmer overens med den utpekte retten. Unntak kan tenkes der rettshandlingen gjelder en regeltype som er fremmed i svensk rett eller gjelder rettslige kategorier som ikke har noe samsvar i svensk rett, i så fall kan det være nødvendig å modifisere anvendelsen av disse rettshandlingene. Hvilke modifikasjoner som er nødvendige overlates til den praktiske rettsanvendelsen. ${ }^{60}$ I domstolens nærmere vurdering trekkes hensynet til partenes forutsetninger og innrettelse i den tro at avtalen er gyldig, inn, og dessuten at avtalen vil være gyldig og kunne oppfylles i iransk rett. Disse hensynene taler for å godta avtalens gyldighet. Momenter som ifølge domstolen, trekker i motsatt retning er at avtalen ble ansett å stride sterkt imot svensk familierett og de prinsippene som den er bygd på og dette blir avgjørende for at svensk materiell rett likevel pekes ut og anlegges i saken.

Prinsippene det vises til er at det er grunnleggende i svensk rett at ektefeller i liten grad skal kunne inngå forhåndsavtaler om fremtidige formuesoverføringer. Videre legges det vekt på at de hensyn som avtalen om mahr skulle oppfylle, vil oppfylles gjennom å anlegge den svenske ekteskapslovgivningen. Her siktes det nok til at en deling av boet i stor grad vil bety en lik fordeling mellom ektefellene etter svensk rett. Når det først er stadfestet at svensk rett skal gjelde fullt ut i saken, blir selve prøvingen kortfattet og reiser ikke vanskelige spørsmål. Avtalen anses som en avtale om fremtidig bodeling, som ikke er gyldig etter den svenske ekteskapsloven kapittel 9 § 13, og kvinnen får altså ikke medhold i sitt krav om at den skal oppfylles. ${ }^{61}$ Jeg leser dommen som at det her foretas en vurdering av forbudet mot forhåndsavtaler om bodelingen i svensk rett som en internasjonalt preseptorisk regel som vil gjelde uavhengig av lovvalgsreglene. Et interessant poeng her er at domstolen samtidig vurderer hvorvidt hensynet som avtalen skulle ivareta (kvinnens økonomiske stilling ved ekteskapets slutt) vil sikres tilstrekkelig gjennom å bruke svensk lov. I dommen gjøres det

\footnotetext{
${ }^{60}$ Regjeringens proposition 1989/90:87 om vissa internationella frågor rörande makars förmögenhetsförhållanden, s. 46-47 (heretter også omtalt prop. 1989/90:87).

${ }^{61}$ For nærmere analyse av dommen, så vel som notisfallet se Jänterä-Jareborg 2018 og Brattström og Sayed 2019.
} 
derfor en materiell bedømming av resultatet i saken i selve lovvalgsvurderingen. I og med at svensk rett anses å ivareta hensynet som den utenlandske inngåtte avtalen hadde som formål om å sikre, er det ikke nødvendig å opprettholde den i svensk rett, når den samtidig strider mot svenske regler som er sterkt prinsipielt begrunnet. I dette henseende er dommen et interessant eksempel på en bred og gjennomtenkt balansering av både lovvalgshensyn og andre hensyn i vurderingen av avtalens gyldighet i svensk rett.

Høgsta domstolen henvisning til hensyn til partenes forutsetninger og forventninger, samt hensyn til at avtalen ville kunne søkes oppfylt etter iransk rett er begge klassiske hensyn i internasjonal privatrett. Domstolen kommer likevel til at avtalen står så langt fra svensk familierett og de prinsipper den bygger på at det ikke vil være aktuelt å anse den som gyldig. Svensk rett pekes dermed ut fullt ut både formelt og materielt å gjelde i saken.

I lys av dommen kan det stilles spørsmål om det bør tas særskilte hensyn til kvinner som er bosatt i Iran og andre muslimske land der mahr er et vilkår for å inngå ekteskap, og som gifter seg i disse landene med noen bosatt i Norge, i vurderingen av lovvalget og kontraktens gyldighet. Begrunnelsen i den svenske dommen for å velge svensk rett var at partene hadde hatt sine livsinteresser i Sverige i en lang periode og derfor kunne anses å ha en tilknytning til det svenske rettssystemet som tilsa at svensk rett skulle anlegges materielt i saken og at svensk rett ville føre til et resultat for kvinnen som tilgodeså henne på en måte som mahravtalen ellers ville ha hatt som formål. Det ble videre lagt vekt på at avtalen ville være sterkt i strid med reglene som gjaldt i svensk rett og de prinsipper som de svenske reglene bygde på (avsnitt 36).

Men dette kan være strenge krav å stille overfor kvinner som ikke kjenner noe annet ekteskapssystem enn det der mahr er en fullstendig integrert og obligatorisk del av ekteskapskontrakten, i hvert fall i saker der kvinnen i forholdet har opprettholdt en sterk tilknytning til opprinnelseslandet og der ekteskapet har vært kortvarig. Å se særskilt på kvinnens situasjon vil kan hende være enda mer aktuelt i en norsk enn i en svensk sammenheng på grunn av at vår regel om skjevdeling nok vil slå ut mer uheldig for innvandrerkvinner enn slik delingsreglene er i svensk rett. Når Høgsta domstolen argumenterer med at svensk lov vil ivareta kvinnen på en måte som mahr-avtalen hadde som formål og at dette tilsier at svensk rett skal gjelde fullt ut på tvisten, så henspiller nok det på at det normalt deles likt mellom ektefellene etter svensk rett. I norsk rett ville i et tilsvarende 
tilfelle mannen i forholdet kunne ta ut det han eide før ekteskapet ble inngått (og eventuelt det han hadde fått i løpet av ekteskapet i arv eller gave) jf. el § 59. For kvinner som kommer på familieinnvandring vil typisk dette kunne slå uheldig ut og man kan tenke seg at avtaler om mahr vil spille en selvstendig rolle i å sikre kvinnen økonomisk også ved ekteskapets slutt.

Poenget her må være at domstolen burde vurdere saken i et kjønnsperspektiv, for å forsikre seg om at ikke reglene rammer kvinner skjevt på grunn av at de er kvinner. Det er ikke dermed sagt at utfallet i slike saker alltid bør være til kvinners fordel, men at saken bør ses i et kjønnsperspektiv nettopp for å avdekke negative effekter av slike avtaler som rammer det ene kjønn hardere enn det andre. ${ }^{62}$

\section{Nærmere om selve vurderingen av mahr-avtaler etter at lovvalget er fastlagt}

\section{Innledning}

Når lovvalget først er foretatt skal saken løses i tråd med det utpekte landets rett, men det kan være nye problemstillinger som dukker opp i selve rettsanvendelsen. Jeg skal nå se nærmere på noen slike problemstillinger knyttet til behandlingen av avtaler om mahr, som bunner i hensyn til rimelighet, rettslig systematikk og likestilling som kan være vanskelig å avveie i rettsanvendelsen.

\section{Der utenlandsk rett velges}

Dersom utenlandsk rett ble valgt ville dette, $i$ et tilfelle som i den svenske dommen, bety at iransk rett skulle anvendes i saken. Dersom avtalen var gyldig etter iransk rett, skulle den altså bli gjennomført etter sitt innhold.

Det er riktignok ikke slik at det endelige resultatet ville bli at avtalen legges til grunn som gyldig i norsk rett. Det ville, som nevnt, kunne være preseptoriske regler i det norske

\footnotetext{
${ }^{62}$ Se Sayed og Linton 2017 for en vurdering av underliggende faktorer i notisfallet. De tar opp en problemstilling om at kvinnen i saken argumenterte med at et resultat dersom avtalen om mahr ble ansett som ugyldig etter svensk rett, ville være at hun ville få vanskeligheter med å få mannen med på å gi henne en uformell, religiøs skilsmisse ettersom hun da ikke ville kunne benytte brudegaven som et forhandlingskort i en slik prosess. Dette kan også være et eksempel på at å kjenne mahr-avtaler ugyldig, kan få ulike avledede konsekvenser i det praktiske liv som det kan det være grunn til å få en økt oppmerksomhet rundt både i domstolene og i samfunnet for $\varnothing$ vrig. Det vil nok riktignok ofte være stor usikkerhet forbundet med å vurdere slike mer avledede konsekvenser. Se Jänterä-Jareborg 2018 og Brattström, M. og M. Sayed 2019. Jeg går ikke nærmere inn denne særskilte problemstillingen i denne artikkelen. Se for $\varnothing$ vrig Wærstad 2017 kapittel 11 for en bredere analyse av betydningen av tradisjonell muslimsk familierett for kvinner når boet skal deles $\mathrm{i}$ forbindelse med skilsmisse i norsk rett.
} 
rettssystemet som ville overstyre lovvalget. Avtalen måtte også vurderes ut ifra om resultatet av den ville stride mot ordre public. Det nærmeste grunnlaget er at avtalen ville slå svært hardt ut mot den mannlige ektefellen. Således vil det være mulig å anføre reglene om urimelige kontrakter mellom ektefeller som preseptoriske (el $\S 46$ og 65), eventuelt komme til at avtalens resultat strider mot ordre public. Det kan reises spørsmål om ikke avtaler om utsatt mahr som vil ramme ektemannen hardt økonomisk dersom han må utbetale den, herunder avtaler som stipulerer verdier som ektemannen ikke eier ved avtaleinngåelsen, er urimelige. Dette vil kun ramme menn og har derfor et kjønnsperspektiv. Avtalen gjør det vanskelig for menn å bryte ut av ekteskapet dersom de ikke kan betale den stipulerte brudegaven. Her kan underkjennelse av avtalen begrunnes på ulike måter rettslig, både med diskrimineringsrettslige og kontraktsrettslige urimelighetsregler. I en sak om gyldigheten av en avtale om mahr bør det unders $\varnothing$ kes hvorvidt slike momenter gjør seg gjeldende. Både diskrimineringsrettslige regler og kontraktsrettslige regler vil kunne anvendes enten som preseptoriske eller i en vurdering av ordre public.

\section{Der norsk rett velges}

Dersom norsk rett velges vil avtalen måtte vurderes etter norsk rett. I den svenske dommen kom man frem til at avtalen var en forhåndsavtale om skiftet. Det er ikke anledning til å inngå en slik avtale etter svensk rett før delingen er umiddelbart forestående jf. den svenske

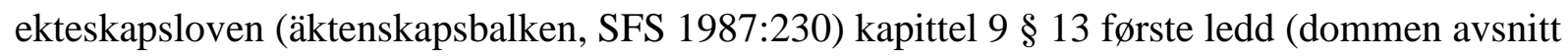
31). Avtalen ble kjent ugyldig på dette grunnlaget (dommen avsnitt 42). Når det gjelder forhåndsavtaler om bodelingen har vi tilsvarende regler i norsk rett. Kapittel $9 \mathrm{i}$ ekteskapsloven (el) regulerer uttømmende hvilke avtaler ektefeller kan inngå om formuesordningen og det er først ved delingen at det er avtalefrihet for ektefellene jf. el $\S$ $56 .{ }^{63}$ En avtale som den som var gjenstand for den svenske dommen ville således ganske klart heller ikke være gyldig etter norsk rett.

En kan tenke seg tilfeller hvor et slikt resultatet kunne få konsekvenser for bodelingen for $\emptyset$ vrig riktignok. En kan for eksempel se for seg at et slikt resultat ville kunne få betydning for vurderingen av et eventuelt krav fra mannen om skjevdeling. Man kunne tenke seg bruk av

\footnotetext{
${ }^{63}$ Dersom ektefellene ønsker å inngå en mahr-avtale som skal være gyldig etter norsk rett i forkant av delingen må de altså følge reglene i ekteskapsloven av 4 . juli 1991 nr. 47 (heretter ekteskapsloven eller el.) kapittel 9. Dette vil innebære å lage en gyldig ektepakt der verdiene det er snakk om kan gjøres til kvinnens eneeie og særeie, men dette fordrer at det er midler som er overført til henne. Mannen vil altså ikke ha anledning til å binde seg til å overføre midler i fremtiden som han ikke er eier av ved avtaleinngåelsen. Dette er riktignok utenfor temaet for denne artikkelen ettersom det vil gjelde regler i intern rett og ikke reise spørsmål om internasjonal privatrett.
} 
unntaksreglene i $§ 59$ slik at ektemannen fikk begrenset sin rett til skjevdeling gjennom el $\S$ 59 andre ledd dersom det $\emptyset$ konomiske resultatet i saken ville være åpenbart urimelig for kvinnen. Her ville det at hun ikke fikk tilkjent brudegaven kunne være et moment i en slik vurdering.

\section{Mellomløsninger?}

Så langt har vi sett på tilfeller der lovvalget enten følger norsk eller utenlandsk rett.

Spørsmålet som jeg vil se på her er om det kan tenkes at det er rom for mellomløsninger. Jeg tar utgangpunkt i den svenske dommen, der det, som beskrevet over, ble vurdert om avtalen om mahr kunne anses gyldig selv om svensk rett ble pekt ut av lovvalgsreglene. Så vidt meg bekjent er det ingen rettskilder, herunder rettslitteratur som behandler dette spørsmålet direkte. Det er dog, som den svenske saken viser, hensyn som tradisjonelt er tillagt stor betydning og har stor aktualitet i internasjonal privatrett som vil gjøre seg gjeldende med hensyn til denne problemstillingen. Dette er hensynet til at partene har forutsatt at de har inngått en gyldig avtale som de forventer at kan oppfylles gjennom rettslige midler. Videre er det hensynet til at man ikke skal få såkalt «haltende» resultater, altså at avtalen er ugyldig etter norsk rett, men kan oppfylles etter iransk rett. Det kan også anføres at ulike regler vi har om å godkjenne avtalers form som er laget under og oppfyller formkravene i et utenlandsk rettssystem selv om disse ikke stemmer overens med de norske formkravene - slik som arveloven $\S 54$ - er underbygget av de samme hensynene. De svenske forarbeidene som det vises til i den svenske dommen, gjør anvisning på at det vil være mulig å tilpasse (modifisere) avtalen i det enkelte tilfellet. ${ }^{64} \mathrm{Høgsta} \mathrm{domstolen} \mathrm{går} \mathrm{riktignok} \mathrm{ikke} \mathrm{inn} \mathrm{på} \mathrm{noen} \mathrm{slik} \mathrm{vurdering}$ om avtalen kunne modifiseres til å passe med svensk rett, ettersom at den finner at avtalen ville være en forhåndsavtale i strid med äktenskapsbalken (SFS 1987:230) kapittel 9 § 13. Den aktuelle bestemmelsen ble ansett for å være av så stor betydning, samt underbygget av sentrale prinsipper i svensk rett, slik at avtalen måtte anses å ikke kunne lempes til å passe med svensk rett i så måte. Det ble også lagt vekt på at det i svensk rett er slik at hensynene til ektefellenes $\emptyset$ konomiske stilling etter endt ekteskap, ivaretas gjennom lov og ikke gjennom avtale. I og med at en slik løsning som svensk rett gjør anvisning på som en del av lovvalgsvurderingen, helt synes å mangle noen parallell i norske rettskilder og ikke har vært diskutert i litteraturen, synes det å holde med å skissere enkelte synspunkter.

${ }^{64}$ Prop. $1989 / 90: 87$ s. $46-47$. 
Gitt at avtalen ikke brøt med sentrale prinsipper som norsk ekteskapsrett bygger på, slik som internasjonalt preseptoriske regler eller ordre public, vil det være mulig at tenke seg en tilpasning i norsk rett. I en situasjon hvor det lempes vil det kan hende kunne gå an å respektere tilknytningen avtalen har til utenlandsk rett, forventningene og forutsetningene til partene og til en viss grad oppnå bedre rettsenhet med landets rett som avtalen er laget under. Man kan for eksempel tenke seg at avtalen skjæres til gjennom rimelighetssensurreglene i ekteskapsloven kapittel 9. Hvorvidt reglene om urimelighetssensur kan anses å være internasjonalt preseptoriske regler er diskutert i teorien. ${ }^{65}$ Frantzen skriver også om tilpasning av utenlandsk rett innenfor rammen av internasjonal privatrett inspirert blant annet av tysk rett, men en slik fremgangsmåte har ikke satt noen egentlige spor i norsk rett. ${ }^{66}$ Det ville i så fall være snakk om å tilpasse den iranske avtalen slik at kvinnen i forholdet ikke fikk fordeler både etter norsk rett og iransk rett, men for eksempel slik at avtalen ble tilpasset til et resultat som ga henne det mest fordelaktige resultatet av de to landenes rett (under forutsetning at et slikt resultat ville være i tråd med norsk ordre public.) ${ }^{67}$ Man kunne for eksempel få en løsning der resultatet ble at hun fikk oppfylt den stipulerte verdien av brudegaven dersom det oversteg det hun ville ha krav på etter norsk rett, men at hun ikke ville bli tilkjent noe mer. På denne måten ville rimelighetsvurderinger med grunnlag i den norske familieformuerettslige lovgivningen, samt andre sentrale hensyn som reiser seg i saker med utenlandsk tilknytning kan hende bli bedre ivaretatt. I denne sammenheng kan det være på sin plass å nevne at mahr utgjør en integrert del av en muslimsk ekteskapskontrakt som kan få økonomiske følger for den av partene som vil bryte ut av ekteskapet. Spesielt for kvinner fremstår en familieøkonomi som følger tradisjonell muslimsk familierett, som uheldig, sammenlignet med menn. ${ }^{68}$ Betydningen dette bør få i en rettssak om gyldigheten av en avtale om mahr, er riktignok ikke klar. Ofte vil de systematiske ulempene i den enkelte sak bli utjevnet av positive følger for kvinnen av den konkret kontrakten som skal vurderes av domstolen. Dette gjør den vanskelig å vurdere. Likevel bør det være en bevissthet rundt dette spørsmålet i de nordiske domstolene der en søken etter rimelige løsninger og muligheter innenfor rammen av internasjonal privatrettslige hensyn, samt hensyn til partene, der både kultur og kjønn bør inngå.

\footnotetext{
65 Frantzen 2002, s. 426-429, S også Holmøy og Lødrup 2001, s. 157.

${ }^{66}$ Frantzen 2002, kapittel XIII.

${ }^{67}$ Jänterä-Jareborg, M. 2018 har lignende synspunkter om tilpasning («anpasning») på den svenske dommen.

${ }^{68}$ Se Wærstad 2017 kapittel 11.
} 


\section{Avslutning}

Denne artikkelen har gjennomgått typiske lovvalgspørsmål som reiser seg når tvister om avtaler om den muslimske brudegaven (mahr) blir reist i en norsk sammenheng. Jeg har sett særlig på lovvalget for avtaler om formuesordningen, som er det mahr-avtaler typisk vil kvalifiseres som etter norsk internasjonal privatrett. Lovvalgsregelen, som tar utgangspunkt i partenes første felles domisil, har blitt vurdert nærmere i lyst av en nyere dom fra svensk høyesterett. Den nærmere analysen pekte ut særskilte aspekter ved mahr-avtaler som bør vurderes i saker i norsk rett knyttet til grunnleggende regler om likestilling og rimelighet $\mathrm{i}$ kontraktsforhold, som nordiske domstoler bør være oppmerksomme på i fremtidige saker om slike avtaler.

\section{Litteratur}

Bano, S. 2011. Muslim Marriage and Mahr: The Experiences of British Muslim Women. In Mehdi R. and Nielsen J. (eds.). Embedding Mahr in the European Legal System. DJØF Publishing, Copenhagen.

Bano, S. 2012a. An exploratory study of Shariah councils in England with respect to family law. University of Reading.

Bano, S. 2012b. Muslim Women and Sharia Councils in Britain: Transcending the Boundaries of Community and Law. Palgrave Macmillian.

Bogdan, M. 2014. Svensk internationell privat- och processrätt. Norstedts juridik. Stockholm.

Bredal A. og T. L. Wærstad 2014. Gift, men ugift: Om utenomrettslige religi申se vigsler. Rapport 2014:06, Institutt for samfunnsforskning.

Brattström, M. og M. Sayed 2013. Behandlingen av mahr i samband med bodelning enligt svensk rätt. Juridisk publikation 2/2013, s. 207-226. 
Brattström, M. og M. Sayed 2019. Avtal om Mahr - referat och reflektion med anledning av NJA s 168 och NJA 2017 N 6. Juridisk publikation 1/2019, s. 39-63.

Bull, K. S. 1993a. Avtaler mellom ektefeller. Tano. Oslo.

Bull, K. S. 1993b. “Lovvalg i saker om økonomiske forhold mellom ektefeller.” Tidsskrift for Rettsvitenskap. Vol. 106 (5), pp. 525-542.

Cordes, J, L. Stenseng og P. Lenda 2010. Hovedlinjer i internasjonal privatrett. Cappelen akademisk forlag.

Esposito, J. L. 2001. Women in Muslim Family Law. Syracuse University Press. Syracuse. New York.

Frantzen, T. 2002. Arveoppgj $\phi r$ ved internasjonale ekteskap: Studier av norsk internasjonal privatrett med sarlig vekt på gjenlevende ektefelles rettsstilling. Fagbokforlaget. Bergen.

Fredriksen, K. J. 2011. Mahr (dower) as a Bargaining Tool in a European Context: a Comparison of Dutch and Norwegian Judicial Decisions. I Mehdi R. and J. Nielsen (eds.) Embedding Mahr in the European Legal System. DJØF Publishing, Copenhagen.

Giertsen, J. 1995. Uskifte og lovvalg. Tidsskrift for rettsvitenskap 1995, s.261-324.

Hallaq, W.B, (2009). Sharī'a: Theory, Practice, Transformations. Cambridge University Press. Cambridge.

Holmøy, V. og P. Lødrup 2001. Ekteskapsloven: og enkelte andre lover med kommentarer. Gyldendal Akademisk. Oslo.

Holmøy, V., P. Lødrup og J. Asland 2013. Ekteskapsloven med kommentarer. Bind 1. Gyldendal Juridisk. Oslo.

Jänterä-Jareborg, M. 2018. Rätt och religion i ett mångkulturellt samhälle, Advokaten, 2018, nr. 3 s. $42-49$

Kvisberg, T.E. 2009. Internasjonale barnefordelingssaker. Internasjonal barnebortfфring. Gyldendal Akademisk. 
Løvdal, L. 2008. "Private International Law, Muslim Laws and Gender Equality.” Kvinnerettslig skriftserie 78:2008.

Løvdal, L- 2011. Mahr and Gender Equality in Private International La: The Adjudication of Mahr in England, France, Norway and Sweden. I Mehdi R. and J.Nielsen (eds.) Embedding Mahr in the European Legal System. DJØF Publishing, Copenhagen.

Mehdi, R. 2001. Gender and Property Law in Pakistan: Resources and Discourses. DJØF Publishing. København.

Mehdi R. and J. Nielsen (eds.) 2011. Embedding Mahr in the European Legal System. DJØF Publishing, Copenhagen.

Moors, A. 2011. Mahr Meanings - Dower Dealings: Reflections from Palestine. I Mehdi R. and J.Nielsen (eds.) Embedding Mahr in the European Legal System. DJØF Publishing, Copenhagen.

Nasir, J. J. A. 2009. The Status of Women under Islamic Law and Modern Islamic Legislation. Brill. Leiden.

Nesvik, Marie 2014. Forelesningsnotater i internasjonal privatrett: Person-, familie- og arverett (et tillegg til Helge J. Thues bok). Institutt for privatrett. Skriftserie, 195.

Pålsson, L. 2006. Svensk rättspraxis i internationell familje- och arvsrätt. Norstedts Juridik. Stockholm.

Roald, A. S. 2001. Women in Islam: The Western Experience. Routledge. London and New York.

Sayed, M. 2008. The Muslim Dower (MAHR) in Europe - With Special Reference to Sweden. European Challenges in Contemporary Family Law (red. Boeli-Woelki \& Sverdrup), Intersentia, s. 187-208

Sayed, M og M. Linton. 2017. Kvinnor «i klem» vid bedømming av mångfald? De lege, IUSTUS. Uppsala, s. 123-145.

Thue, H. J. 1997. Formuesordningen i internasjonale ekteskap - de rettslige hovedlinjer. Lov og Rett 1997, s. 34-54. 
Thue, H. J. 2002. Internasjonal privatrett: personrett, familierett og arverett. Gyldendal akademisk. Oslo.

WLUML 2006. Knowing our Rights. Women, family, laws and customs in the Muslim world. London: WLUML.

Wærstad, T. L. 2017. Protecting Muslim Minority Women's Human Rights at Divorce:

Application of the Protection against Discrimination Guarantee in Norwegian Domestic Law, Private International Law and Human Rights Law. Baden-Baden: Nomos 